J. Perinat. Med.

3 (1975) 269

\title{
The measurement of fetal growth during pregnancy by ultra-sound (B-Scan)
}

\author{
E. P. Issel, P: Prenzlau, H. Bayer, R. Lüder, R. Schulte, G. Wohlfahrth, \\ M. Weight, Technical Assistance: Renate Acker
}

Department of Obstetrics and Gynecology, Medical Faculty (Charité), Humboldt University in Berlin

Received April 21, 1975. Accepted July 20, 1975.

Fetal development throughout pregnancy can be followed by chemical, physiological, and physical methods. However, most methods allow only an indirect conclusion from the assay results to the fetus. These methods are indirect because the results include maternal values e. $g$. in the case of hormone assays from maternal blood or urine, measurement of the maternal abdominal girth, the recording of the height of the fundus or the assessment of the maternal weight gain $[3,9]$.

Because the results of measurements have to be corrected for their maternal contribution in order to arrive at conclusions about the fetus, a certain amount of extrapolation is inevitable with these methods. This may interfere in finding an answer to the question of fetal development.

Ultra-sonography can overcome this deficit because it enables us to perform direct measurements on the fetus. Even if the images obtained with the B-scan do not yet achieve the quality of good radiographs and even if the penetration with rapid imaging currently is limited to $15 \mathrm{~cm}$, diagnostic impulse ultrasound is certainly safe [8].

\section{Material and methods}

In a special ultrasound clinic we have performed the following measurements on patients with known post-menstrual gestational ages:

Biparietal diameter of the skull

5400 measurements

sagittal thorax diameter

1500 measurements

\section{Curriculum vitae}

Dr. ERnst Peter Issel was born in 1938 in Berlin. He completed bis medical studies at Humboldt University in Berlin in 1962 and obtained bis degree in 1963 with a thesis on blood group incompatibilities. His training in obstetrics and gynecology was completed in 1968 at the Charité Hospital in Berlin under Professor $H$. Kraatz. From 1970 to 1971 be obtained neonatolog)' training under Professor I. Syllm-Rapoport. Since 1974 be is leader of Obstetric Research at Humboldt University under Professor H. Bayer. His areas of interest are: perinatal epidemiolog)', birth mechanics, birth trauma, neurolog)' of the neonate, late sequelea, pregnancy monitoring, ultrasound, maternal nutrition and biomedical statistics.

length of trunk

1300 measurements

The technique has been described in detail by us elsewhere $[1,11,13]$. We have used the "Vidoson 635" apparatus by SIEMENS. This is a B-scan with rapid imaging. The apparatus is calibrated against a phantom simulating the distribution of sound in muscle $(1568 \mathrm{~m} / \mathrm{sec})$. The reference plan for the biparietal diameter is the largest obtainable skull diameter with a clear median echo so that a measurement at right angle can be made. The thorax is measured in that plane in which it has its largest dimension with still visible cardiac 
apical action. The vertebral column is the landmark for the direction of the measurement. The distance from shoulder to coccyx (trunk) was measured from the top of the shoulder adjacent to the base of the skull to the tip of the coccyx and was corrected for horizontal and sagittal deviation of the fetal position according to Pythagoras' law. The percentile values for each week of gestation were entered into diagrams and the resulting curves were then smoothened. Only these smoothened curves are published. For the illustration of the biparietal diameter we had sufficient measurements so that no smoothening process was needed. Smoothening of the other curves was accomplished by calculating means with the values from the preceding and succeeding weeks.

$\therefore$

The trunk measurements were treated as follows:

\begin{tabular}{lll} 
Percentile & $\begin{array}{l}\text { Number of Data } \\
\text { Points within } \\
\text { one gestational } \\
\text { week }\end{array}$ & $\begin{array}{l}\text { Graphical depic- } \\
\text { tion in the } \\
\text { illustrations }\end{array}$ \\
\hline 50 & $\begin{array}{l}\text { up to } 4 \\
5-11\end{array}$ & $\begin{array}{l}\text { none } \\
\text { interrupted line } \\
\text { solid line }\end{array}$ \\
25 or 75 & $\begin{array}{l}12 \text { and more } \\
\text { up to } 19\end{array}$ & $\begin{array}{l}\text { none } \\
\text { interrupted line } \\
\text { solid line } \\
\text { none }\end{array}$ \\
10 or 90 & $\begin{array}{l}40 \text { and more } \\
\text { up to } 39\end{array}$ & $\begin{array}{l}\text { nonterrupted line } \\
40 \text { to } 99\end{array}$ \\
100 and more & solid line \\
\hline
\end{tabular}

Some cases in which evidently impossible gestational dates were given were excluded, i. e. if the patient's date differed with the clinical findings by 8 weeks or more. No other exclusions were made. Thus these percentile curves include in addition to normal pregnancy cases with maternal disease and intrauterine growth retardation. For the biparietal diameters after the 38th gestational week we had cases which were corrected after the birth of the child when it was evident that the gestational duration had been miscalculated, i. e. the clinical diagnosis of fetal maturation differed from maternal dates by more than 4 weeks. Therefore, the curves of the biparietal diameter do not show the divergence towards the end of the pregnancy usually seen in unselected material.

In Figure 1 we have demonstrated the development of the biparietal diameter as a function of the week of gestation. With the aid of this curve it can be determined whether in cases of known gestational age the biparietal diameter developed normally. If several measurements are

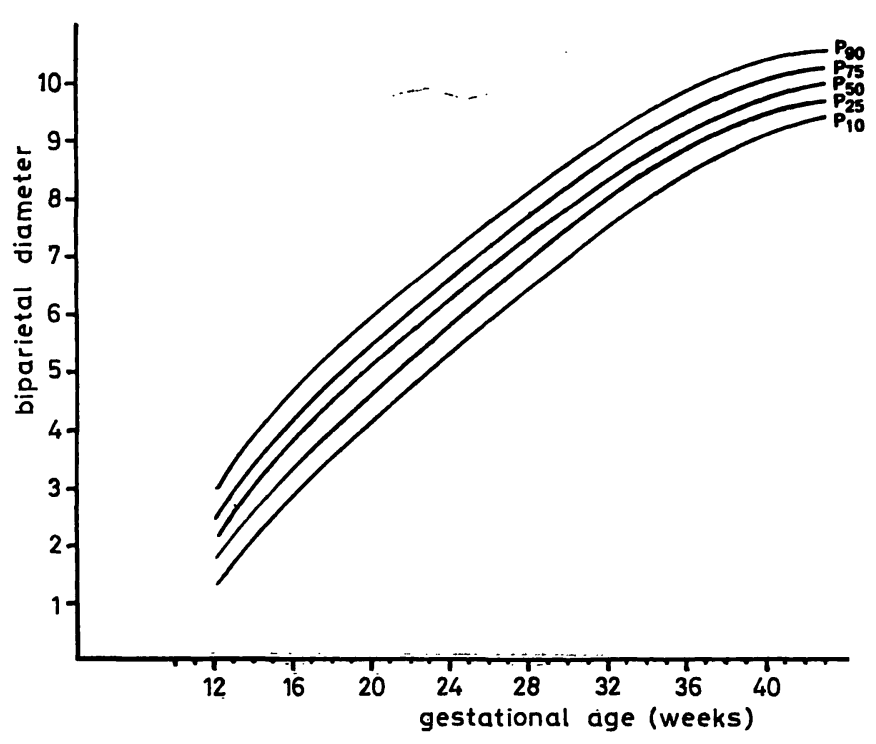

Fig. 1. Weeks of gestation versus biparietal diameter.

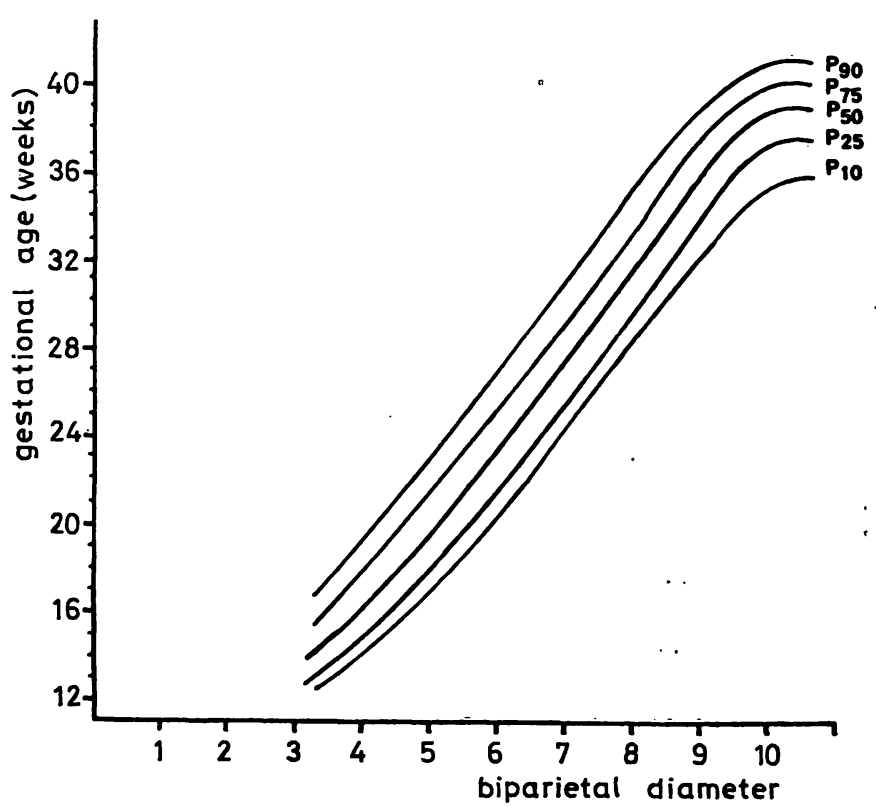

Fig. 2. Biparietal diameter versus gestation weeks. 
available and the gestational age is not known one may attempt to fit findings to the 50th percentile line and thus in addition to evaluating the increase in the increments of the biparietal diameter also calculate the estimated time of birth. In Figure 2 we depict the probability to which point a pregnancy has progressed if with unknown gestational duration a measurement of the biparietal diameter is made for the first time. It is seen how small errors of measurement influence the estimation of the gestational duration markedly. Therefore, repeated measurements for verification are always advisable. Because of the shallow slope of this curve toward both ends, it is recommended to use only values between 4.0 and $9.2 \mathrm{~cm}$ for determination of gestational age. Great caution is advisable with larger and smaller measurements.

Figure 3 demonstrates the sagittal thoracic diameter as a function of the week of gestation. With this curve we can assess whether the fetal thorax developed normally during gestation or whether it lags in relation to the growth of the

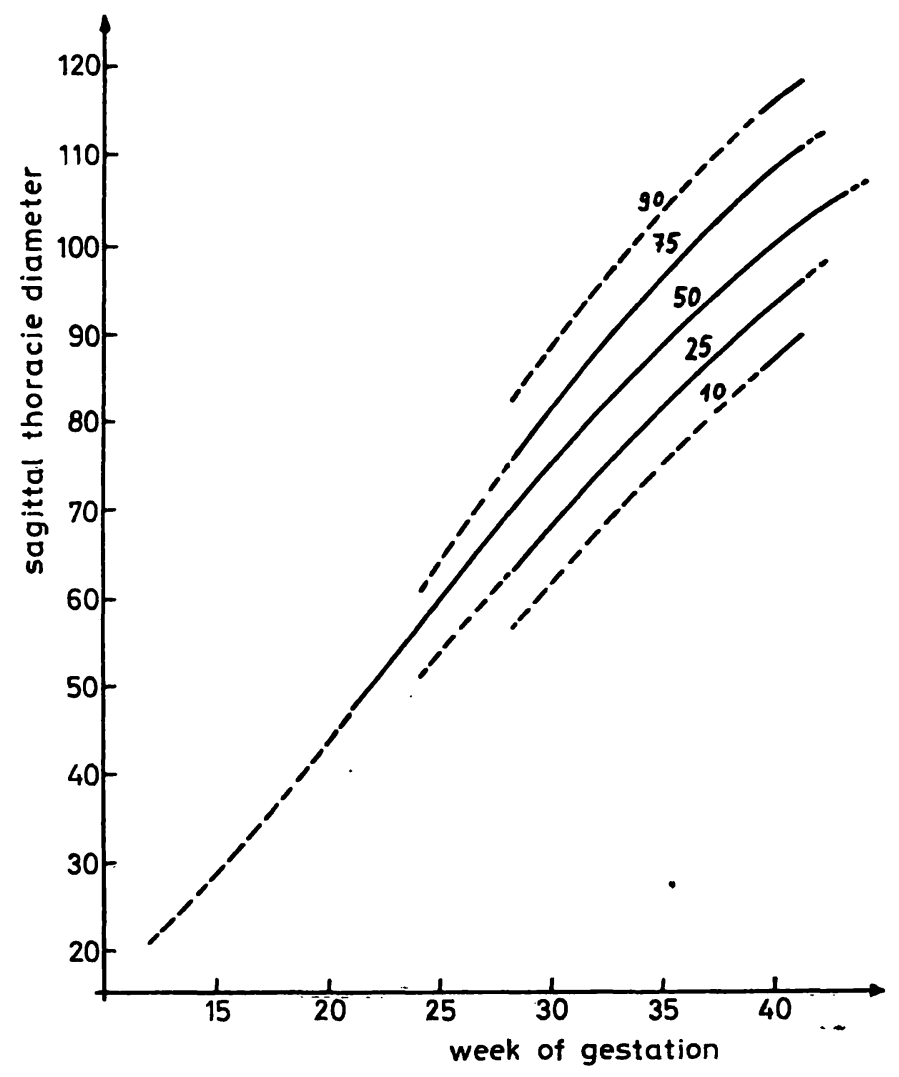

Fig. 3. Weeks of gestation versus sagittal thoracic diameter.

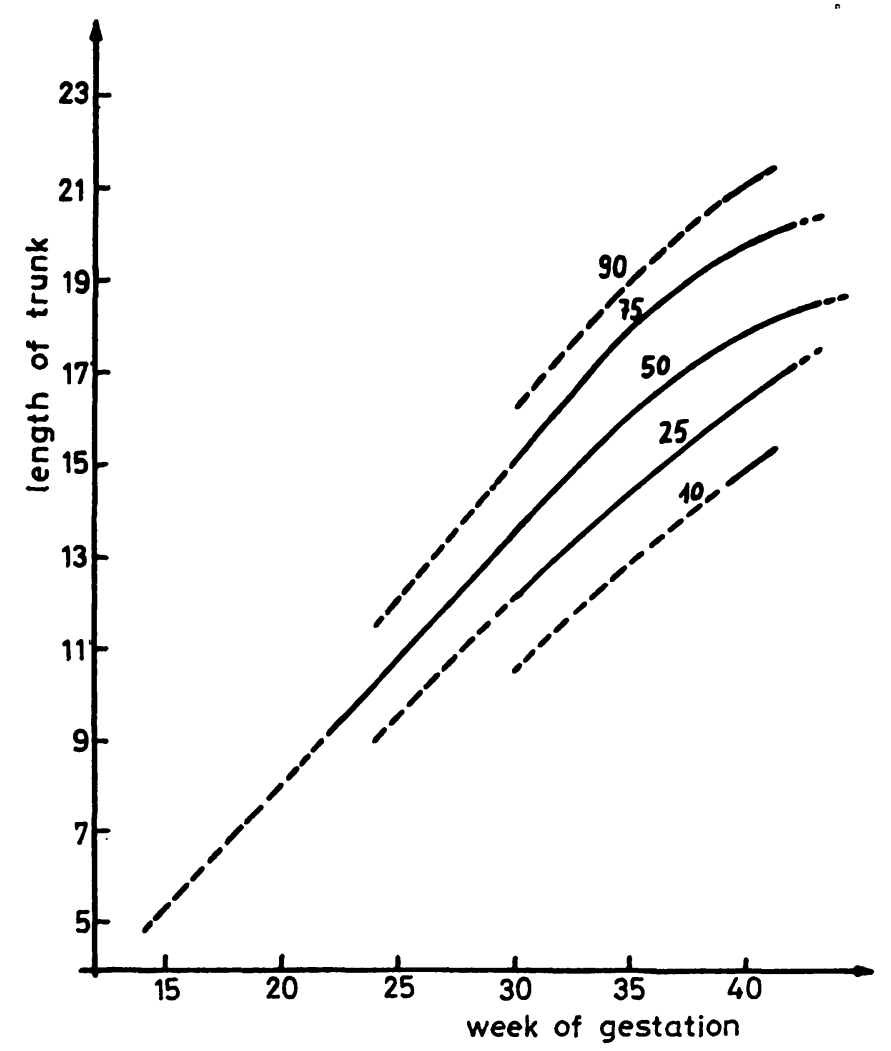

Fig. 4. Weeks of gestation versus length of trunk.

fetal skull (dystrophy) or whether its growth is accelerated relatively (hypertrophy).

The length of the trunk as illustrated in Figure 4 is primarily utilized as a control for the relations between biparietal diameter and sagittal thoracic diameter. It aids in identifying errors in measurement by unfavorable conditions of projection or because of malformations. It is important to determine whether the measurement for the length of the trunk falls in the same percentile area as the sagittal thoracic diameter. Figure 5 illustrates this problem further. A comparison of the length of the trunk and the sagittal thoracic diameter points out the fact that with a thoracic sagittal diameter of $11 \mathrm{~cm}$ or more, the trunk length decreases again. This can be ascribed to fetal presentations unfavorable for the projection of the planes of measurement. Appropriate techniques can eliminate these methodological errors only partially. These techniques consist of repositioning of the patient and tilting the probe until the thorax has a circular appearance in the reference plane; this causes the least amount of distortion. 


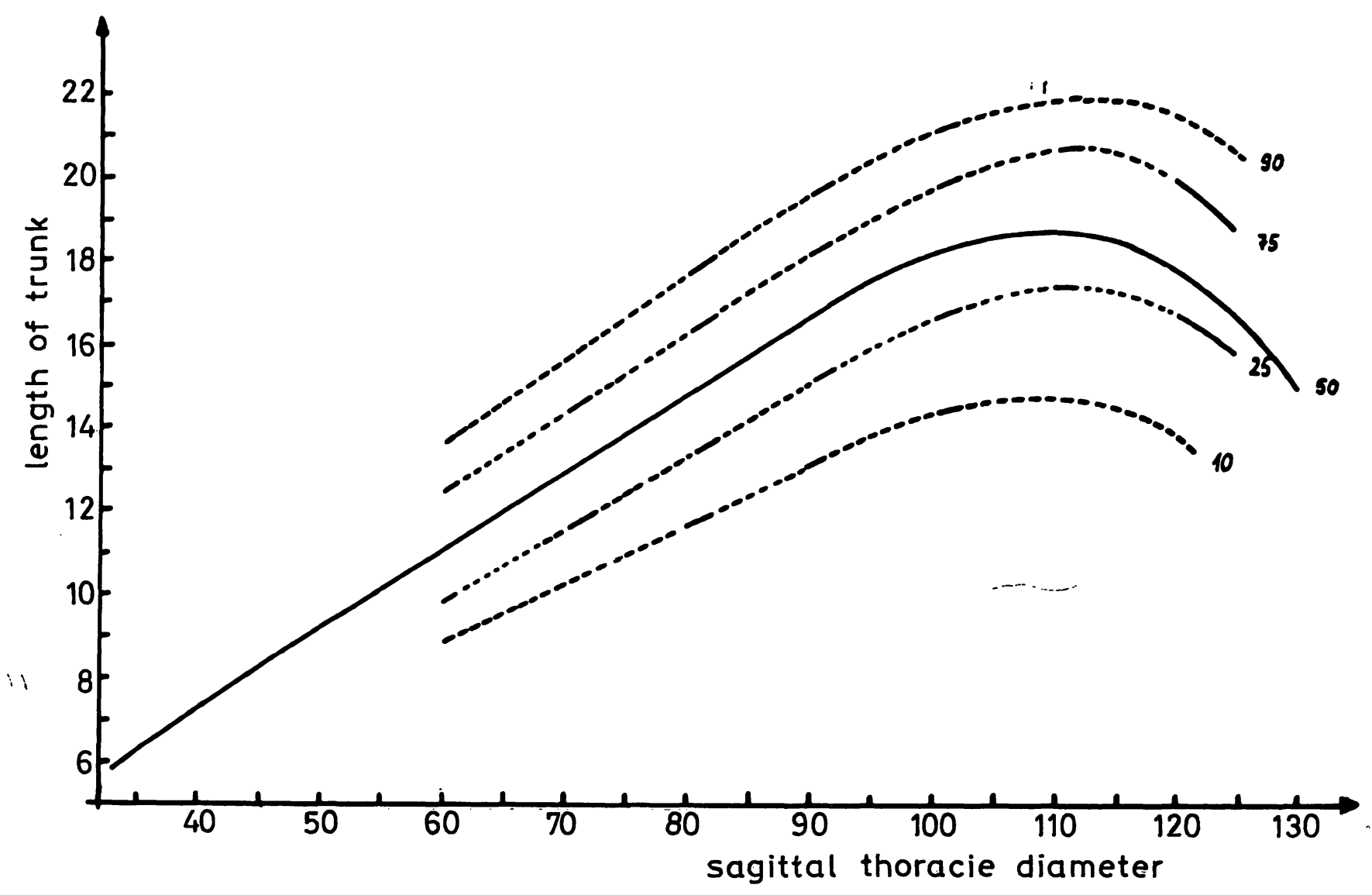

Fig. 5. Sagittal thoracic diameter versus length of trunk.

\section{Discussion}

Publications about fetal monitoring by ultrasonography usually offer a mean curve of the biparietal diameter with one or two standard deviations. We believe $[5,6,7]$ that instead of mean values one should use percentile values because they are less influenced by extremes. The "correction" of values thus obtained may introduce uncontrol label subjective errors. We have also pointed out the necessity to include trunk measurements for fetal monitoring $[1,13]$. With this opinion we concur with HaNSMANN and co-workers [7] who also consider the exclusive use of the biparietal skull diameter for the evaluation of the fetal development as insufficient.

The percentile curves for the sagittal thoracic diameter obtained by HANSMANN et al. [7] are comparable with those found by us. Our curves are almost identical to those of HANSMANN et al. except that our scatter corresponding to the 90 th and 10th percentiles correspond to $95 \%$ of all values in their publication. HANSMANN et al. excluded pathological pregnancies which might result in disturbed fetal development. The figures for the mean by SCHLENSKER [15] are at least $1 \mathrm{~cm}$ below our values for the 50 th percentile for sagittal thoracic diameter. We were unable to explain this difference; possibly a different reference plane was used.

Measurement of the fetal trunk support the findings from the other measurements specifically in cases in which because of positional anomalies of the fetus the biparietal diameter can be determined only with limited accuracy. Furthermore, the trunk measurements identify discrepancies of the development between. trunk and skull if they are in different percentiles than the biparietal diameter. If the trunk measurements are small in relation to the skull fetal dystrophy should be suspected, if they are larger maternal diabetes should be considered.

Murata and Martin [12] demonstrated that the biparietal diameter of the fetus grows faster in cases of maternal diabetes than in normal cases only after the 37 th week of gestation. 
IFFY et al. [10] reported several fetuses which were too large in cases of placenta previa.

Discrepancies in trunk measurements from biparietal diameter may also indicate fetal anomalies. Thus we were able to diagnose fetal microcephalus in two cases. Our percentile curves of biparietal diameter may be compared with publications by CAMPRELL, mean .curve; [4] and Campbell and Newman, percentile curve, [5]. The 50th percentile of our curves (Fig. 1) is roughly identical to that of CAMpBeLL and Newman [5]. While the curves are quite identical at both ends the intermediate values published by Campbell and Newman are higher by $2-3 \mathrm{~mm}$. This 50th percentile however is recommended for use only in Middle Europe. The different weight-percentile curves for the various geographical areas allow the conclusion that mean values for biparietal diameters in other continents should be determined separately for these areas. It is remarkable that the spread for the biparietal diameter is much larger than those of CAMPBELL and Newman [5].

Their curves for the 5th and 95th percentiles correspond to our 25th and 75th percentiles. We interpret this as representing the selection of the patient material by these authors while our material is almost entirely unselected. Almost certainly incorrect histories by patients as to their dates have increased the variation in our curves. On the other hand detailed investigation on gestational duration by SAITO and co-workers [14] have confirmed a considerable variation. Even if the date of conception is known only $49 \%$ of deliveries occur within the 38th and 39th completed weeks of gestation and $91 \%$ occur within the 36th to 40th completed weeks.

Consequently we believe that a greater amount of variation has to be taken into account for fetal development as a function of gestation duration. The additional introduction of the methodological errors of ultrasonography adds to the variation.

A difference in the course of the 50th percentile has been published by BoLTe et al. [2]. Our curve after the 26th week is steeper but runs flatter after the 38th week. The differences are as much as $1 \mathrm{~cm}$ and we consider this curve less suitable for practical application.

\section{Summary}

We have followed fetal growth by ultrasonographic Bscans. In addition to percentile curves of the biparietal skull diameter we have established percentile curves for measurements of the fetal trunk (sagittal thoracic diameter and length of trunk). The percentile curves for the biparietal diameter were obtained from 5400 individual measurements; the percentile curves for the trunk measurements utilized 1300 individual measurements. These cases were from almost entirely unselected material from our special prenatal clinic.

This resulted in a larger variation than the percentile curves for biparietal diameter of other authors [CAMPBELL and NewmaN]. However, these authors selected their material for "normal pregnancy" while we insured that neither "corrections" of the normal variation nor subjective criteria for exclusion have introduced a systematic error.

The advantages of ultrasonography for monitoring of the pregnancy are self-evident: repeated examinations are possible, the examination takes little time, and the method

is safe. The determination of the biparietal diameter for estimation of fetal development alone is insufficient because trunk measurements may indicate developmental disturbances (dystrophy and hypertrophy) before the growth of the biparietal diameter of the skull is affected.

Furthermore, comparison of the fetal skull and trunk measurement may indicate errors in measurement or malformations (hydrocephalus, microcephalus). The following percentile curves are illustrated graphically:

1. Gestational age versus biparietal diameter (Fig. 1).

2. Biparietal diameter versus weeks of gestation (Fig. 2).

3. Length of gestation versus sagittal thoracic diameter (Fig. 3).

4. Length of gestation versus length of trunk (Fig. 4).

5. Sagittal thoracic diameter versus length of trunk (Fig. 5).

Keywords: Biparietal diameter, fetal development, obstetrics, sagittal thoracic diameter, trunk length, ultrasound. 


\section{Zusammenfassung}

Das Wachstum des Fetus in der Schwangerschaft gemessen mittels Ultraschall (B-scan)

Mittels der Ultraschall-B-Bildtechnik haben wir die fetale Entwicklung verfolgt. Neben Perzentilenkurven für den biparietalen Schädeldurchmesser haben wir Perzentilenkurven für Rumpfmaße des Fetus (sagittaler Thoraxdurchmesser und Trunkuslänge) publiziert. Für die Aufstellung der Perzentilenkurven für den biparietalen Schädeldurchmesser wurden 5400 Einzelmessungen verwertet, für die Aufstellung der Perzentilenkurven für die Rumpfmaße etwa 1300 Einzelmessungen. Es handelt sich bei diesen Fällen um ein fast unausgelesenes Material unserer Spezialsprechstunde.

Dadurch werden, wie wir im Vergleich mit den Perzentilenkurven für den biparietalen Schädeldurchmesser anderer Autoren feststellen konnten (CAMPBELL und NEwMAN), die Schwankungsbreiten zwar größer gegenüber ausgewählten Kollektiven von „Normalschwangerschaften", wir sind jedoch dafür sicher, daß wir weder durch „Beschneiden“ der natürlichen Variationsbreite inoch durch subjektive Auswahlkriterien einen systematischen Fehler hineingebracht haben.

Die Vorteile der Anwendung der Ultraschalltechnik zur Überwachung der Schwangerschaft - beliebige Anzahl

Schlüsselwörter: Biparietaler Schädeldurchmesser, fetale Entwickliung, Geburtshilfe, sagittaler Thoraxdurchmesser, Trunkuslänge, Ultraschall.

\section{Résumé}

La croissance du foetus en cours de grossesse mesurée par ultra-son (B-scan)

Nous avons observé le développement foetal au moyen de la technique de l'image ultrasonique $B$. En plus des courbes de pourcentage pour le diamètre crânial bipariétal, nous avons publié des courbes similaires pour la dimension du tronc du foetus (diamètre du thorax sagittal et longueur du tronc). A cet effet, nous avons évalué 5400 mesures séparées pour établir les courbes de pourcentage pour le diamètre crânial bipariétal et environ 1300 pour les courbes relatives à la mensuration du tronc. Il s'agit dans ces cas d'un matériel pour ainsi dire non sélectionné de notre consultation spéciale.

Comme nous avons pu le constater en comparant avec les courbes de pourcentage pour le diamètre crânial bipariétal d'autres auteurs (CAMpbell et NewMAN), les marges d'oscillation sont, bien entendu, plus grandes que pour les groupes sélectionnés de "grossesses normales", mais, par contre, nous sommes certains d'avoir évité toute erreur systématique puisque nous n'avons pas «rétréci» le champ naturel de variation ni influencé les résultats par des critères de sélection subjectifs.

Les avantages de l'application de la technique ultrasonique sont évidents pour la surveillance de la grossesse (nombre von Kontrollen möglich, geringer Aufwand der Untersuchung, Unschädlichkeit der Methodik - sind evident. Die Beurteilung des biparietalen Schädeldurchmessers zur Einschätzung der Entwicklung der Frucht ist allein unzureichend, da am Rumpf noch vor der Retardierung der Größenzunahme des biparietalen Schädeldurchmessers Hinweise für eine Entwicklungsstörung zu finden sind (Dystrophie und Hypertrophie).

Ferner kann man durch Vergleiche der fetalen Schädelund Rumpfmaße Hinweise für Fehlmessungen und Mißbildungen erhalten (Hydrozephalus, Mikrozephalus). Folgende Perzentilenkurven sind abgebildet:

1. Schwangerschaftsdauer gegen den biparietalen Schädeldurchmesser (Fig. 1),

2. biparietaler Schädeldurchmesser gegen Schwangerschaftswoche (Fig. 2),

3. Schwangerschaftsdauer gegen sagittalen Thoraxdurchmesser (Fig. 3),

4. Schwangerschaftsdauer gegen Trunkkuslänge (Fig. 4),

5. sagittaler Thoraxdurchmesser gegen Trunkuslänge (Fig. 5) non limité de contrôles, frais peu élevés de l'examen, mépariétal ne suffit pas à lui seul pour évaluer le développement de l'embryon car on peut trouver dans le tronc des indices de trouble du développement (dystrophie et hypertrophie) avant même que n'apparaisse un retardement de l'allongement du diamètre crânial bipariétal.

De plus, il est possible de détecter des anomalies dans les mensurations et la formation du foetus en comparant les mesures du crâne et du tronc chez le foetus (hydrocéphalie, microcéphalie).

Nous avons établi les courbes de pourcentage suivantes:

1. Durée de grossesse contre le diamètre crânial bipariétal (Fig. 1),

2. diamètre crânial bipariétal contre la semaine de grossesse (Fig. 2),

3. durée de grossesse contre le diamètre du thorax sagittal (Fig. 3),

4. durée de grossesse contre la longueur du tronc (Fig. 4),

5. diamètre du thorax sagittal contre la longueur du tronc (Fig. 5).

Mots-clés: Développement du foetus, diamètre crânial bipariétal, diamètre du thorax sagittal, longueur du tronc, obstétrique, ultra-son. 


\section{Bibliography}

[1] Bayer, H., E. P. Issel, R. Schulte: Neue Meßgrößen bei der Erkennung einer intrauterinen Retardierung der Frucht mittels Ultraschalldiagnostik. Zbl. Gynäk. 94 (1972) 1169

[2] Bolte, A., F. H. Ch. SalzmanN, K.-H. Schlensker: Zur pränatalen Bestimmung des fetalen Reifegrades. Fortschr. Med. 91 (1973) 67

[3] Casaer, P., Y. Akiyama: The estimation of the postmentrual age: a comprehensive review. Developm. Med. Child Neurol. 12 (1970) 697

[4] Campbell, S.: The prediction of fetal maturity by ultrasonic measurement of the biparietal diameter. J. Obstet. Gynaec. Brit. Cwlth. 76 (1969) 603

[5] Campbell, S., G. B. Newman: Growth of the fetal biparietal diameter during normal pregnancy. J. Obstet. Gynaec. Brit. Cwlth. 78 (1971) 513

[6] Flamme, P.: Ultrasonic fetal cephalometry: Percentiles curve. Brit. Med. J. 3 (1972) 384

[7] HansmanN, M., H. Bäker, St. Fabula, H. MüllerScholtes, H. J. Nellen, U. Voigt: Biometrische Daten des Feten. Ergebnisse einer modifizierten Methodik der Ultraschall-Diagnostik. In: SALING, E., J. W. Dudenhausen: Perinatale Medizin. Band III. 4. Deutscher Kongreß für Perinatale Medizin. Berlin 1971. Thieme, Stuttgart 1972

This paper is dedicated to Prof. Dr. Möbius on the occasion of his 60 th birthday.
[8] HOLLÄNDER, H.-J.: Die Ultraschalldiagnostik in der Schwangerschaft. Urban und Schwarzenberg, München-Berlin-Wien 1972

[9] Hytren, F. E., T. LIND: Diagnostic indices in pregnancy. Ciba-Geigy, Basel (Schweiz 1973

[10] Iffy, L., R. T. Chatterton, A. Jakobovits: The "high weight for dates" fetus. Amer. J. Obstet. Gynec. 115 (1973) 238

[11] Issel, E. P., P. Prenzlau: Eine neue Methode zur Berechnung des fetalen Gewichtes mittels Ultraschall - B - Bild - Technik. Zbl. Gynäk. 96 (1974) 417

[12] Murata, Y., C. B. Martin jr.: Growth of the biparietal diameter of the fetal head in diabetic pregnancy. Amer. J. Obstet. Gynec. 115 (1973) 252

[13] Prenzlau, P., E. P. Issel: Die praktische Bedeutung der Messung der Schulter-Steißlänge (Trunkometrie) beim Fetus mittels Ultraschall. Zbl. Gynäk. 95 (1973) 1421

[14] Saito, M., K. Yazawa, A. Hashiguchi, T. KumaSAKA, N. Nishi, K. Kato: Time of ovulation and prolonged pregnancy. Amer. J. Obstet. Gynec. 112 (1972) 31

[15] Schlensker, K.-H.: Eine Ultraschallmethodik zur Thorakometrie beim Feten. Geburtsh. u. Frauenheilk. 33 (1973) 440

Dr. E. P. Issel

Univ.-Frauenklinik

Tucholskystr. 2

DDR 104 Berlin 